\title{
Review Board Approval Number Text
}

National Cancer Institute

\section{Source}

National Cancer Institute. Review Board Approval Number Text. NCI Thesaurus. Code C93662.

A character string that is assigned by the review board upon approval of the protocol. 